\title{
Association of IL1B -511C/-31T haplotype and Helicobacter pylori vacA genotypes with gastric ulcer and chronic gastritis
}

\author{
Dinorah N Martínez-Carrillo, Elvira Garza-González², Reyes Betancourt-Linares³, Trinidad Mónico-Manzano', \\ Cuauhtémoc Antúnez-Rivera', Adolfo Román-Román', Eugenia Flores-Alfaro ${ }^{4}$, Berenice Illades-Aguiar ${ }^{5}$, \\ Gloria Fernández-Tilapa ${ }^{1 *}$
}

\begin{abstract}
Background: The association between proinflammatory cytokine gene polymorphisms and gastric diseases related to Helicobacter pylori varies by population and geographic area.

Our objective was to determine if the $I L-1 B-511 T>C$ and $-31 C>T$ polymorphisms and $H$. pylori vacA genotypes are associated with risk of chronic gastritis and gastric ulcer in a Mexican population.

Methods: We conducted endoscopic studies in 128 patients with symptoms of dyspepsia. We took two biopsies from the body, antrum, or ulcer edge from each patient, and classified our histopathological findings according to the Sydney System. H. pylori infection and vacA genotyping were accomplished via PCR from total DNA of the gastric biopsies. We confirmed the presence of anti-H. pylori serum IgG and IgM in 102 control subjects. In both case subjects and control subjects, the $I L-1 B-511 T>C$ polymorphism was genotyped by PCR-RFLPs and the $I L-1 B$ -31 C>T polymorphism was genotyped by pyrosequencing.

Results: Sixty-two point seven (62.7\%) of the 102 control subjects were H. pylori-seropositive. Among the case subjects, 100 were diagnosed with chronic gastritis and 28 with gastric ulcer. We found that $77 \%$ of the patients with chronic gastritis and $85.7 \%$ of the patients with gastric ulcer were $H$. pylori-positive. The predominant $H$. pylori genotype was vacA s1m1 (58.4\%) and the most frequent subtype was vacA s1. The -511 TC, (rs16944 -511 T>C) genotype and the -511C allele were associated with chronic gastritis $(\mathrm{OR}=3.1,95 \% \mathrm{Cl}=1.4-6.8$ and $\mathrm{OR}=3.0,95 \% \mathrm{Cl}=1.4-6.0$, respectively). The subjects carrying -31T (rs1143627-31 C>T) were found to be at a higher risk of having chronic gastritis ( $\mathrm{OR}=2.8,95 \% \mathrm{Cl}=1.3-5.8)$. The IL-1B -511C/-31T haplotype was associated with chronic gastritis $(\mathrm{OR}=2.1,95 \% \mathrm{Cl}=1.2-3.8)$ but not with gastric ulcer.

Conclusions: The $\mathrm{H}$. pylori vacA genotypes identified herein were similar to those reported for other regions of Mexico. The vacA $51 \mathrm{~m} 1$ genotype was not associated with gastric ulcer. In the southern Mexican population, the $I L-1 B-511 C$ and $-31 T$ alleles and the -511C/-31T and -511T/-31T haplotypes are associated with increased risk of chronic gastritis and gastric ulcer.
\end{abstract}

\section{Background}

Helicobacter pylori infection is related to the inflammatory response of the gastric mucosa. While most infected individuals remain asymptomatic, persistent colonization and chronic inflammation increase the risk of developing

\footnotetext{
* Correspondence: gferti@hotmail.com

'Laboratorio de Investigación Clínica, Unidad Académica de Ciencias

Químico Biológicas, Universidad Autónoma de Guerrero. Av. Lázaro Cárdenas S/N. Ciudad Universitaria, Colonia Haciendita, Chilpancingo, Guerrero. C.P. 39090, México

Full list of author information is available at the end of the article
}

atrophic gastritis, peptic ulcers, and distal gastric adenocarcinoma [1]. The development of chronic gastritis is the initiating event in the process that leads to stomach cancer. The risk of malignancy increases with severity, chronicity, and duration of the inflammatory process [2,3]. Clinical outcome of $H$. pylori infection is determined by the genetic characteristics of the host and bacteria as well as environmental factors [4]. While $H$. pylori is considered to be a class I carcinogen, it is accepted that some genotypes have greater virulence. The strains

\section{Ciomed Central}


that express cytotoxin-associated gene A (CagA) and large quantities of vacuolating cytotoxin (VacA) are most frequently found in patients with peptic ulcers and gastric carcinoma $[2,5,6]$. It has been observed that $H$. pylori $v a c A s 1 / m 1$ strains produce high levels of the cytotoxin, strains $s 1 / m 2$ produce moderate levels, and strains $s 2 / m 2$ produce little or no toxin $[7,9]$. The $v a c A s 1$ subtype is related to higher disease severity and a higher risk of developing ulcers and stomach cancer $[5,6,10]$.

$H$. pylori induce production of IL- $1 \beta$ in the gastric mucosa. IL-1 $\beta$ modulates the expression of other proinflammatory cytokine genes such as TNF- $\alpha$, IL-2, IL-6 and IL-12, which increase the magnitude of inflammation [11]. The concentration of IL- $1 \beta$ produced by the inflamed epithelium is influenced by two biallelic polymorphisms in positions $-511 \mathrm{~T}>\mathrm{C}(\mathrm{rs} 16944)$ and $-31 \mathrm{C}>\mathrm{T}$ (rs1143627). These polymorphisms are in almost total genetic disequilibrium, and -31 is a TATA-box polymorphism that significantly affects DNA-protein interactions in vitro. Thus, these single-nucleotide polymorphisms (SNPs) can modulate production of IL- $1 \beta$, directly affecting transcription $[12,13]$. Given that IL- $1 \beta$ is a strong inhibitor of gastric acid secretion and may contribute to dispersion of H. pylori from the pylorus to the corpus of the stomach, polymorphisms in the IL- $1 \beta$ gene can be considered a key genetic factor in determining the pattern of gastritis that develops and one risk of malignant transformation $[13,14]$. The $I L-1 B-511 T$ and $-31 C$ alleles are associated with high levels of the cytokine and with severe inflammation or stomach cancer, in comparison to $-511 \mathrm{C}$ and $-31 T$, which are associated with low levels of IL-1 $\beta$. This association with $H$ pylori infection or stomach cancer has not been significant in all populations [2,4,6,11,13-20].

In combination, bacterium virulence factors and $I L-B$ polymorphisms $\left(\mathrm{cag} A+/ v a c A+/ I L-1 B-511 T / I L-R N^{*} 2\right)$ are associated with severe histological changes in the gastric mucosa of some populations $[1,4]$. However, the variability of results across populations and geographic areas has been a source of ongoing controversy [2,13,14]. While gastritis, ulcer, and duodenitis constitute the fourth leading cause of disease in the Mexican population [21], the genetic basis for inter-individual variations in inflammatory response and cytokine production, in the context of $H$. pylori infection, has not been well studied in the Mexican population.

Genotyping of $H$. pylori vacA and $I L-1 B$ polymorphisms could be important in the early identification of individuals at high risk for developing severe gastric diseases. The objective of this study was to evaluate the relationship between $I L-1 B-511 T>C$ and $-31 C>T$ polymorphisms and the presence of chronic gastritis and gastric ulcer, and to analyze the relationship of $H$. pylori $v a c A$ genotypes with gastric ulcer.

\section{Methods}

\section{Population}

We studied 128 patients subjected to an endoscopic study in the Specialized Unit for Gastroenterology Endoscopy in the city of Chilpancingo, in the state of Guerrero, Mexico, from April 2007 to May 2008. All subjects suffered from functional dyspepsia, epigastric pain, and ulcerative syndrome. Patients who had not received H. pylori erradication therapy, and had not been treated with proton pump inhibitors nor with gastric $\mathrm{pH}$ neutralizers during the two months prior to the endoscopy were included in the study. We also studied 102 subjects without dyspepsia symptoms, from the same population as the cases, with no history of $H$. pylori infection or gastroduodenal diseases. In both groups, we excluded subjects under non-steroidal anti-inflammatory drug (NSAID) treatment.

Informed consent was obtained from participants or their parents. Participants' eating habits, socio-demographic factors, family history of gastritis or ulcers, alcohol consumption, and smoking habits were recorded via surveys. The study was approved by the Bioethics Committee of the Universidad Autónoma de Guerrero.

\section{Endoscopy and gastric histology}

For each patient, endoscopy was carried out using a video processor and video gastroscope (Fujinon, Wayne, NJ, USA). From each patient, we took two biopsies from the antrum, corpus, or ulcer edge; one specimen was immediately fixed in formalin for histological testing and the other was placed in buffer solution (Tris $10 \mathrm{mM}$ pH 8.0, EDTA $20 \mathrm{mM}$ pH 8.0, SDS 0.5\%) for $H$. pylori diagnosis. The biopsies intended for $H$. pylori detection were kept at $-20^{\circ} \mathrm{C}$ until processing. The histological sections were stained with hematoxylin-eosin and evaluated by a pathologist using the updated Sydney System criteria [22]. Endoscopic observation and histopathological confirmation were used to determine patient pathology.

\section{Serology}

Blood samples $(5 \mathrm{ml})$ were taken from all control subjects. The serum was tested for IgG and IgM anti- $H$. pylori by enzyme-linked immunosorbent assay (ELISA; International Immuno-Diagnostics, Foster City, CA, USA) according to the manufacturer's instructions. The sensitivity and specificity of this method are $96 \%$ and $97 \%$, respectively. A subject was considered $H$. pyloripositive if we detected at least one of the two antibodies.

\section{H. pylori detection and vacA genotyping}

Total DNA was extracted from the gastric biopsies of each patient via the phenol:chloroform:isoamilic alcohol technique, after digestion with proteinase $\mathrm{K}$ [23]. 
In the cases, the presence of $H$. pylori was detected by polymerase chain reaction (PCR) for the $16 \mathrm{~S}$ rRNA gene. We used $150 \mathrm{ng}$ total DNA, $2.5 \mathrm{mM} \mathrm{MgCl} 2,0.2 \mathrm{mM}$ dNTPs (Invitrogen, Carlsbad, CA, USA), 10 pmol of each oligonucleotide, and $1 \mathrm{U}$ Platinum ${ }^{\oplus}$ Taq DNA Polymerase (Invitrogen, Carlsbad, CA, USA) in a final volume of $15 \mu \mathrm{L}$. The $H$. pylori-positive samples were subjected to detection of subtypes of $v a c A$ by PCR. For PCR of the signal region (s) and medium (m), we used $300 \mathrm{ng}$ total DNA, $1.5 \mathrm{mM} \mathrm{MgCl}_{2}, 0.2 \mathrm{mM}$ dNTP, 15 pmol of each oligonucleotide, and $1 \mathrm{U}$ Platinum ${ }^{\odot}$ Taq DNA Polymerase in a final volume of $20 \mu \mathrm{L}$. The amplification protocols were previously described by Atherton et al. and Park et al. [24,25]. In each PCR, we used DNA from strain ATCC43504, vacA $s 1 / m 1$ as positive control for $H$. pylori and for $v a c A$ genotypes. The template DNA was substituted with sterile deionized water in the negative control. All PCRs were conducted in a Mastercycler ${ }^{\circledR}$ Ep gradient thermal cycler (Eppendorf, Hamburg, Germany).

\section{IL-1B -511 T>C and -31 C>T genotyping}

We obtained peripheral blood DNA from the control subjects using Miller's technique [26]. Genotyping of the $I L-1 B-511 T>C$ SNP was done via PCR-restriction fragment length polymorphism (RFLP) as previously described [1]. Eight-microliter of PCR product were digested with $2 \mathrm{U}$ AvaI (New England Biolabs, Ipswich, MA, USA) at $37^{\circ} \mathrm{C}$ for $12 \mathrm{~h}$ and analyzed in $2 \%$ agarose gels. The $I L-1 B-31 C>T$ SNP was genotyped by pyrosequencing, following the methodology described by Pérez et al. [27]. Of the 230 samples processed, $12 \%$ were subjected to PCR-RFLP for genotype verification.

\section{Statistical Analysis}

We applied $\mathrm{X}^{2}$ or Fisher's exact test to compare frequencies between groups, and analysis of variance (ANOVA) or Kruskal-Wallis tests to compare means and medians, respectively. In the control group, we evaluated the Hardy-Weinberg Equilibrium (HWE) for $I L-1 B$ polymorphisms. To determine the association of $I L-1 B$ polymorphisms with chronic gastritis and gastric ulcer, we evaluated binomial and polynomial logistic regression models, and used multiplicative interaction models to study the effect of possible interactions between $H$. pylori and $I L-1 B$ genotypes and gastric ulcer. We calculated Lewontin's D' statistic for linkage disequilibrium between loci. Two-tailed statistical tests were conducted with a significance level of 5\% using STATA 10 software.

\section{Results}

\section{Histological diagnosis}

Of the 128 patients examined, 78.1\% had chronic gastritis and $21.9 \%$ had gastric ulcer. The majority of cases and controls were women. The average age was 29 years for controls (range 17-61), 46 years for chronic gastritis cases (range 11-80), and 56 years for gastric ulcer patients (range 25-83). There were significant differences among the three groups in age, years of schooling, geographic origin, family history of gastritis or ulcer, and smoking habits $(\mathrm{p}<0.05)$, table 1 .

\section{$H$. pylori infection and vacA genotypes}

In 64/102 (62.7\%) control subjects anti-H. pylori antibodies were detected; 47 control subjects (46.1\%) were positive for either IgG or IgM and 17 (16.7\%) were IgG +/IgM+. Of the 128 cases, 101 (78.9\%) were H. pyloripositive, and the prevalence varied by diagnosis. One $v a c A$ genotype was detected in $85 / 101$ (84.2\%) infected subjects and two genotypes were detected in $15 / 101$ (14.8\%) subjects. The $s 1 m 1$ genotype was detected in $59 / 101(58.4 \%)$ infected subjects, $s 1 m 2$ was detected in $37 / 101$ (36.6\%), s2m2 in 19/101 (18.8\%), and $s 1 m 1 / s 1 m 2$ in 15/101 (14.8\%) infected subjects. One sample did not amplify for $m$ subtypes. Genotypes $s 1 m 1$ and $s 1 m 2$ were predominant in the two groups of cases, table 2. Most, $97 / 116$ (83.6\%), typed subtypes were vacA $s 1$. The s1variant was detected in $22 / 25(88 \%)$ of the patients with ulcer and 75/91(82.4\%) of those with gastritis. Co-infection with $s 1 \mathrm{~m} 1 / \mathrm{s} 1 \mathrm{~m} 2$ genotypes was more frequent in patients with chronic gastritis (18.2\%) than in those with gastric ulcer (4.2\%). There was not significant association between the $H$. pylori $s 1$ subtype and gastric ulcer (OR $=1.9,95 \% \mathrm{CI}=0.29-12.8, \mathrm{p}=0.48)$ as compared to chronic gastritis. $H$. pylori infection was associated with chronic gastritis $(\mathrm{OR}=2.3,95 \% \mathrm{CI}=1.2-4.1, \mathrm{p}=0.009)$ and with gastric ulcer $(\mathrm{OR}=4.0,95 \% \mathrm{CI}=1.3-12.5, \mathrm{p}=$ 0.016) as compared to controls.

\section{IL-1B -511 T>C and -31 C>T polymorphisms}

In the control group, the $-511 T>C$ and $-31 C>T I L-1 B$ SNPs genotypes were in Hardy-Weinberg equilibrium (HWE) (for SNP $-511 \mathrm{X}^{2}=0.500, \mathrm{p}=0.479$; for SNP $\left.-31 \mathrm{X}^{2}=0.014, \mathrm{p}=0.905\right)$. The genotypic frequencies of the $I L-1 B-511 T>C$ and $-31 C>T$ SNPs were significantly different between the patient and control groups $(-511 T>C, \mathrm{p}=0.015 ;-31 C>T, \mathrm{p}=0.027)$. For rs16944 $(-511 \mathrm{~T}>\mathrm{C})$, the frequency of genotype $\mathrm{TC}$ was greater in patients with gastritis $(60 \%)$ and ulcer $(46.4 \%)$ than in control subjects (38.2\%). Genotype CC was the most frequent in patients with gastric ulcer $(17.9 \%)$. The genotype frequency distribution for rs1143627 (-31 C>T) CT was $57.1 \%$ among patients with gastric ulcer, $52 \%$ among patients with chronic gastritis, and $41.2 \%$ among controls. Genotype TT was more frequent in individuals with gastritis. The $I L-1 B-31 T$ allele was the most frequent among patients with chronic gastritis and ulcer compared to control subjects, table 3. Concordance of results between pyrosequencing and PCR-RFLP 
Table 1 Socio-demographic characteristics in cases and controls

\begin{tabular}{|c|c|c|c|c|}
\hline \multirow[b]{2}{*}{ Characteristic } & \multirow[b]{2}{*}{$\begin{array}{l}\text { Controls } \\
(n=102)\end{array}$} & \multicolumn{2}{|c|}{ Cases } & \multirow[b]{2}{*}{ p-value } \\
\hline & & $\begin{array}{l}\text { Chronic gastritis } \\
(n=100)\end{array}$ & $\begin{array}{l}\text { Gastric ulcer } \\
(\mathrm{n}=\mathbf{2 8})\end{array}$ & \\
\hline Age (mean \pm sd; years) & $29.8 \pm 11$ & $46.1 \pm 14.6$ & $56.3 \pm 17.1$ & $<0.001^{\epsilon}$ \\
\hline \multicolumn{5}{|l|}{ Gender $n(\%)$} \\
\hline Female & $65(63.7)$ & $64(64)$ & $19(67.9)$ & $0.917^{\boldsymbol{\theta}}$ \\
\hline Male & $37(36.3)$ & $36(36)$ & $9(32.1)$ & \\
\hline Education [mean (range); years] & $12(12-17)$ & $12(6-17)$ & $6(0-12)$ & $<0.001^{\dagger}$ \\
\hline \multicolumn{5}{|l|}{ Geographical area $\mathrm{n}(\%)$} \\
\hline Chilpancingo & $44(43.1)$ & $30(30)$ & $5(17.9)$ & $0.021^{\theta}$ \\
\hline Other municipalities & $58(56.9)$ & $70(70)$ & $23(82.1)$ & \\
\hline Family history of gastritis and/or ulcer $n(\%)$ & & & & $0.001^{\boldsymbol{\theta}}$ \\
\hline No & $49(48.0)$ & $39(39.0)$ & 22 (78.6) & \\
\hline Yes & $53(52.0)$ & $61(61.0)$ & $6(21.4)$ & \\
\hline \multicolumn{5}{|l|}{ Smoking habit $\mathrm{n}(\%)$} \\
\hline No & $39(38.2)$ & $65(65)$ & $10(35.7)$ & $<0.001^{\boldsymbol{\theta}}$ \\
\hline Current smoker or former smoker & $63(61.8)$ & $35(35)$ & $18(64.3)$ & \\
\hline \multicolumn{5}{|l|}{ Alcohol consumption $\mathrm{n}(\%)$} \\
\hline No & $14(13.7)$ & $22(22)$ & $7(25)$ & $0.211^{\boldsymbol{\theta}}$ \\
\hline Consumes or consumed & $88(86.3)$ & $78(78)$ & $21(75)$ & \\
\hline
\end{tabular}

${ }^{\epsilon}$ ANOVA test; ${ }^{\dagger}$ Kruskal-Wallis test; ${ }^{\theta} \mathrm{X}^{2}$ Test; ${ }^{\Omega}$ Fisher's exact test.

genotyping of $-31 \mathrm{C}>\mathrm{T}$ SNP was $96.4 \%$. Linkage disequilibrium was almost complete between $I L-1 B-31$ and $I L$ $1 B-511$ in the case subjects $\left(\mathrm{D}^{\prime}=0.97 ; \mathrm{p}<0.001\right)$.

The $-511 T C /-31 C T$ genotypes were more frequent among patients with chronic gastritis $(48 \%)$ and patients with gastric ulcer (42.9\%); in contrast, the $-511 T T /$ $31 C C$ combination was present in $29 \%$ and $32.1 \%$ of these groups, respectively. $C T / T T$ of $I L-1 B-31 C>T$ SNP was associated with the presence of chronic gastritis $(\mathrm{OR}=2.8,95 \% \mathrm{CI}=1.3-5.8, \mathrm{p}=0.006)$ but not with the presence of gastric ulcer, table 4. Adjusting for age, place of origin, schooling, smoking habits, family history of gastritis or gastric ulcer, and H. pylori infection, $T C /$ $C C$ of $I L-1 B-511 T>C$ SNP was significantly associated

Table 2 Genotype and alleles of $H$. pylori vacA frequencies in cases

\begin{tabular}{|c|c|c|c|}
\hline \multirow[t]{2}{*}{ Genotypes or alleles } & \multicolumn{2}{|c|}{ Cases } & \multirow[t]{2}{*}{ p-value } \\
\hline & $\begin{array}{c}\text { Chronic gastritis } \\
\mathrm{n}(\%)\end{array}$ & $\begin{array}{c}\text { Gastric ulcer } \\
n(\%)\end{array}$ & \\
\hline \multicolumn{4}{|l|}{ Genotypes } \\
\hline $\operatorname{sim} 1$ & $31(40.2)$ & $13(54.1)$ & $0.254^{\Omega}$ \\
\hline $\operatorname{sim} 2$ & $16(20.8)$ & $6(25.0)$ & \\
\hline$s 2 m 2$ & $16(20.8)$ & $3(12.5)$ & \\
\hline $\operatorname{sim} 1$ y $\operatorname{sim} 2$ & $14(18.2)$ & $1(4.2)$ & \\
\hline Not typed * & - & $1(4.2)$ & \\
\hline Total & $77(100)$ & $24(100)$ & \\
\hline \multicolumn{4}{|l|}{ Alleles s } \\
\hline s1 & 75 (82.4) & $22(88.0)$ & $0.551^{\Omega}$ \\
\hline s2 & $16(17.6)$ & $3(12.0)$ & \\
\hline Total & $91(100)$ & $25(100)$ & \\
\hline \multicolumn{4}{|l|}{ Alleles $m$} \\
\hline $\mathrm{m} 1$ & $45(49.5)$ & $14(58.3)$ & $0.187^{\boldsymbol{\theta}}$ \\
\hline $\mathrm{m} 2$ & $46(50.5)$ & $10(41.7)$ & \\
\hline Total & $91(100)$ & $24^{\S}(100)$ & \\
\hline
\end{tabular}

${ }^{*}$ Signal region s1genotype ${ }^{\Omega}$ Fisher's exact test ${ }^{\theta} \mathrm{X}^{2}$ Test.

$\delta^{\prime}$ It was not possible to amplify the $m$ allele in one biopsy.

Table 3 Genotypic distribution and allelic frequencies of IL-1B polymorphisms in cases and controls

\begin{tabular}{|c|c|c|c|c|}
\hline \multirow[b]{2}{*}{$511 \mathrm{~T}>C$ SNP } & \multirow[b]{2}{*}{$\begin{array}{l}\text { Controls } \\
\text { n (\%) }\end{array}$} & \multicolumn{2}{|c|}{ Cases } & \multirow[b]{2}{*}{$p$-value } \\
\hline & & $\begin{array}{c}\text { Chronic gastritis } \\
\text { n (\%) }\end{array}$ & $\begin{array}{c}\text { Gastric ulcer } \\
\text { n (\%) }\end{array}$ & \\
\hline \multicolumn{5}{|l|}{ Genotype } \\
\hline$\pi$ & $53(52.0)$ & $31(31.0)$ & $10(35.7)$ & $0.015^{\theta}$ \\
\hline TC & 39 (38.2) & $60(60.0)$ & $13(46.4)$ & \\
\hline CC & $10(9.8)$ & $9(9.0)$ & $5(17.9)$ & \\
\hline \multicolumn{5}{|l|}{ Allele } \\
\hline T & 0.711 & 0.610 & 0.589 & $0.060^{\theta}$ \\
\hline C & 0.289 & 0.390 & 0.411 & \\
\hline \multicolumn{5}{|l|}{$-31 \mathrm{C}>\mathrm{T}$ SNP } \\
\hline \multicolumn{5}{|l|}{ Genotype } \\
\hline CC & $52(51.0)$ & $31(31.0)$ & $10(35.7)$ & $0.027^{\Omega}$ \\
\hline $\mathrm{CT}$ & $42(41.2)$ & $52(52.0)$ & $16(57.1)$ & \\
\hline$\pi$ & $8(7.8)$ & $17(17.0)$ & $2(7.1)$ & \\
\hline \multicolumn{5}{|l|}{ Allele } \\
\hline C & 0.716 & 0.570 & 0.643 & $0.009^{\theta}$ \\
\hline T & 0.284 & 0.430 & 0.357 & \\
\hline
\end{tabular}

${ }^{{ }^{\theta}} \mathrm{X}^{2}$ Test ${ }^{\Omega}$ Fisher's exact test 
Table 4 Association of IL-1B polymorphisms with chronic gastritis and gastric ulcer

\begin{tabular}{|c|c|c|c|c|c|c|}
\hline \multirow[t]{2}{*}{ SNP } & \multirow[t]{2}{*}{ Model } & \multirow[t]{2}{*}{ Genotype } & \multicolumn{2}{|c|}{ Gastritis } & \multicolumn{2}{|c|}{ Ulcer } \\
\hline & & & OR $(95 \% \mathrm{Cl})$ & p-value & OR $(95 \% \mathrm{Cl})$ & p-value \\
\hline \multirow[t]{5}{*}{$-511 \mathrm{~T}>\mathrm{C}$} & Co-dominant & $\pi$ & $1.0^{*}$ & & $1.0^{*}$ & \\
\hline & & TC & $3.1(1.4-6.8)$ & 0.004 & $2.3(0.7-7.6)$ & 0.175 \\
\hline & & $\mathrm{CC}$ & $2.5(0.7-8.4)$ & 0.148 & $5.0(0.9-29.0)$ & 0.075 \\
\hline & Dominant & $\pi$ & $1.0^{*}$ & & $1.0^{*}$ & \\
\hline & & $\mathrm{TC} / \mathrm{CC}$ & $3.0(1.4-6.3)$ & 0.003 & $2.6(0.8-8.2)$ & 0.094 \\
\hline \multirow[t]{5}{*}{$-31 C>T$} & Co-dominant & $\mathrm{CC}$ & $1.0^{*}$ & & $1.0^{*}$ & \\
\hline & & $C T$ & $2.3(1.1-5.0)$ & 0.035 & $2.6(0.8-8.8)$ & 0.112 \\
\hline & & $\pi$ & $5.6(1.8-17.6)$ & 0.003 & $1.6(0.2-12.6)$ & 0.667 \\
\hline & Dominant & $\mathrm{CC}$ & $1.0^{*}$ & & $1.0^{*}$ & \\
\hline & & $\mathrm{CT} / \mathrm{TT}$ & $2.8(1.3-5.8)$ & 0.006 & $2.5(0.8-7.9)$ & 0.122 \\
\hline
\end{tabular}

* Reference category: healthy individuals. Models adjusted by age, place of origin, education, smoking habit, family history of gastritis or gastric ulcer, and $\mathrm{H}$. pylori infection.

with ulcer and chronic gastritis together, as compared to controls $(\mathrm{OR}=2.9,95 \% \mathrm{CI}=1.4-5.8, \mathrm{p}=0.004)$. Separating by diagnosis, we found association of $-511 T C / C C$ with chronic gastritis $(\mathrm{OR}=3.0,95 \% \mathrm{CI}=1.4-6.3, \mathrm{p}=$ $0.003)$. The $-511 C /-31 T$ and $-511 T /-31 T$ haplotypes were significantly associated with chronic gastritis but not with gastric ulcer, table 5 .

To determine whether carriers of $-511 \mathrm{C}$ and $-31 \mathrm{~T}$ alleles who were infected by $H$. pylori vacA $s 1$ showed higher risk of gastritis or ulcer, the OR was calculated for the patients exposed to $H$. pylori vacA $s 1$ within each group, as compared to those infected with $H$. pylori vacA $s 2$. We did not observe significant association between infection with $H$. pylori vacA $s 1$ with chronic gastritis or gastric ulcer in carriers of the $I L$ $1 B-511 C$ and $-31 T$ alleles or their haplotypes (data not shown).

\section{Discussion}

In patients with chronic gastritis, we only found genotypes $v a c A s 1 m 1, s 1 m 2$, and $s 2 m 2$. However the most virulent allele, vacAs1, was the most frequent in patients with both diseases. Our results agree with those reported by other authors and confirm that the $s 1 m 1$ genotype is in greatest circulation in Mexico [28-30]. The lack of significant association between $v a c A$ s $1 m 1$ with gastric ulcer, as compared to chronic gastritis, may be explained by the presence of multiple factors giving rise to the disease and by the small sample size in our study.

Chronic infection with $H$. pylori induces hypochlorhydria, and this is a critical factor in the development of gastric pathology. Thus, the genetic factors in the host that influence acid secretion can also mediate the clinical progress of $H$. pylori infection. IL-1 $\beta$ is a powerful proinflammatory cytokine that is overexpressed in the presence of $H$. pylori and plays an important role in amplifying the inflammatory response to the infection $[1,6,31,32]$. The biallelic polymorphisms in positions -31 and -511 of $I L-1 B$ influence cytokine expression; allele T in position -31 forms a TATA-Box that can potentiate and induce expression of IL- $1 \beta[32,33]$. It has been reported that the $I L-1 B-511 T / I L-1 B-31 C$ alleles are significantly associated with the development of hypochlorhydria, $H$. pylori infection, gastritis, and stomach cancer, however the variability of results from studies conducted in various populations remain controversial [33-36].

Interestingly, in our study, the $-511 \mathrm{TC} / \mathrm{CC}$ and -31 $C T / T T I L-1 B$ genotypes were associated with the presence of chronic gastritis and the presence of gastric ulcer when all cases were grouped $(-511 \mathrm{TC} / \mathrm{CC}$ OR adjusted $=2.8,95 \% \mathrm{CI}=1.6-5.1 ;-31 C T / T T \mathrm{OR}_{\text {adjusted }}=$ $2.9,95 \% \mathrm{CI}=1.6-5.3)$. Greater risk of chronic gastritis and stomach cancer has also been reported in Japanese population with the $-511 C C$ genotype and in Chinese

Table 5 Haplotypes of IL-1B SNPs and their association with gastritis and gastric ulcer

\begin{tabular}{|c|c|c|c|c|c|c|c|c|c|}
\hline \multirow[t]{2}{*}{ Haplotype } & \multicolumn{2}{|c|}{ SNP } & \multirow[t]{2}{*}{ Controls } & \multicolumn{6}{|c|}{ Cases } \\
\hline & -511 & -31 & & Chronic gastritis & OR $(95 \% \mathrm{CI})$ & p-value & Gastric ulcer & OR $(95 \% \mathrm{Cl})$ & p-value \\
\hline 1 & $\mathrm{~T}$ & C & 0.706 & 0.543 & $1.0^{*}$ & & 0.570 & $1.0^{*}$ & \\
\hline 2 & C & $\mathrm{T}$ & 0.279 & 0.363 & $2.1(1.2-3.8)$ & 0.02 & 0.338 & $1.3(0.2-7.5)$ & 0.97 \\
\hline 3 & $\mathrm{~T}$ & $\mathrm{~T}$ & 0.005 & 0.067 & $16(1.2-221)$ & 0.04 & 0.019 & $\mathrm{ID}$ & \\
\hline 4 & C & C & 0.010 & 0.027 & $3(0.4-24.6)$ & 0.31 & 0.073 & ID & \\
\hline
\end{tabular}

ID: insufficient data. * Reference category. Models adjusted by age, place of origin, education, smoking habit, family history of gastritis or gastric ulcer, and H. pylori infection. 
population with the CT genotype [37]. In the Thai population, $I L-1 B$ genotype $-511 C C$ is considered a risk factor for stomach cancer [38]. A previous study in a Japanese population showed that subjects with the $-31 T T$ genotype had a significantly higher risk of $H$. pylori infection $(\mathrm{OR}=1.74,95 \% \mathrm{CI}=1.15-5.63)$ than subjects with $-31 C T$ or $-31 C C$ genotypes. A similar result was obtained for $H$. pylori-seropositive JapaneseBrazilians $(\mathrm{OR}-31 T T=1.45,95 \% \mathrm{CI}=1.02-2.07)$ $[13,39]$. In a Korean population, the $-31 T$ polymorphism was found to be associated with stomach cancer [33]; and in Polish and Western Scottish populations, the $-31 T$ allele was found to be associated with both $H$. pylori infection and hypochlorhydria as well as a higher risk of stomach cancer [32]. In a Spanish population, García-González et al. found that $I L-1 B-511 \mathrm{C} /-31 \mathrm{~T}$ contributed to risk of duodenal ulcer [40].

In our study, the effect of the $-31 C T / T T$ and $-511 T C /$ $C C$ genotypes on risk of chronic gastritis was greater when we adjusted for factors such as age, place of origin, schooling, smoking habits, family history of gastritis or gastric ulcer, and $H$. pylori infection. Therefore, the habits and lifestyles of the studied individuals modified the risk of developing chronic gastritis. Such findings support the multifactorial model of gastric pathology that includes the host, $H$. pylori, and the environment $[13,36,39]$. Given the OR values, it is likely that the same is true for gastric ulcer, but due to the small size of the sample it was not possible to obtain significant associations.

To our knowledge, this is the first study to examine the association of $-511 T>C$ and $-31 C>T$ SNPs in Mexican patients with chronic gastritis and gastric ulcer. Two prior studies found that the $-31 C C$ genotype was associated with stomach cancer as compared to the $-31 T T$ genotype (in the northeast region of Mexico, OR $=7.6,95 \% \mathrm{CI}=1.73-46.9$; in the southeast and central regions of Mexico, $\mathrm{OR}=3.19,95 \% \mathrm{CI}=1.05-9.68$ ) $[6,41]$. These differences might be the result of genomic diversity in the populations across different regions of Mexico. The sub-population in the northern region of Mexico has a greater contribution of European ancestry, while the population of Guerrero has a particularly dominant African ancestral contribution, with a minor European contribution and is genetically closer to the Zapotecs [42].

Chronic gastritis and gastric ulcer are part of the natural evolution to stomach cancer [3,4], and it is possible that a similar phenomenon occurs in Mexico as has been observed in Asian populations, in which the distribution of $I L-1 B$ genotypes differs between the northern region, where there is a high prevalence of stomach cancer, and the southern region, where there is a low prevalence of stomach cancer [33-35,43].
The information available on $I L-1 B$ alleles associated with diseases linked to $H$. pylori is controversial. While some researchers have found that $I L-1 B-511 T T$ and $I L$ $1 B-31 C C$ are proinflammatory $[32,44]$, others have found, with in vitro experiments and with stomach cancer patients infected with $H$. pylori, that the $I L-1 B$ $-511 C$ and $I L-1 B-31 T$ alleles potentiate expression of IL- $1 \beta$ in the gastric mucosa $[33,45,46]$. The results of our work agree with those of Takagi et al. who found that the $I L-1 B-511 C C / I L-1 B-31 T T$ genotypes potentiate cytokine production and are significantly associated with the clinical development of $H$. pylori infection [47].

\section{Conclusions}

Patients with chronic gastritis and gastric ulcer were infected predominantly with $H$. pylori vacA $\operatorname{sim} 1$ genotype and the vacAs1 allelotype was the most frequent. In chronic gastritis the $\operatorname{sim} 1$ y $\operatorname{sim} 2$ genotypes tend to be associated in co-infections.

In the population of southern Mexico, $-511 C$ or $-31 T$ alleles and $-511 \mathrm{C} /-31 \mathrm{~T}$ or $-511 \mathrm{~T} /-31 \mathrm{~T}$ haplotypes of $I L-$ $1 B$ increase the risk of chronic gastritis and gastric ulcer.

The results of this study support the hypothesis that the combined effect of lifestyle, infection with virulent genotypes of $H$. pylori, and genetic factors of the host, such as $I L-1 B$ $-511 C / I L-1 B-31 T$ polymorphisms, can play an important role in development of chronic gastritis and gastric ulcer in the Mexican population of the state of Guerrero.

\section{Acknowledgements}

The authors wish to thank Elizabeth Rosales-Cruzaley as well as the nurses and support personnel of the Gastroenterologic Endoscopy Specialized Unit of Chilpancingo, who assisted in obtaining samples. We also want to thank Martín O. Morrugares Ixtepan, Specialist in Pathological Anatomy with subspecialty in Oncological Pathology, who was responsible for the histopathological diagnosis. The study was financed by the Secretaría de Educación Pública, via PIFI 2007 and the Programa de Apoyo a la Reincorporación de Exbecarios PROMEP 2007, key PROMEP UAGUER-EXB096. During our study, Dinorah Nashely was a grant recipient of the Consejo Nacional de Ciencia y Tecnología de México. Finally, we would like to thank Dinorah Leyva-Illades (Texas A\&M Health Science Center) for translating this manuscript to the English language.

\section{Author details}

${ }^{1}$ Laboratorio de Investigación Clínica, Unidad Académica de Ciencias Químico Biológicas, Universidad Autónoma de Guerrero. Av. Lázaro Cárdenas S/N. Ciudad Universitaria, Colonia Haciendita, Chilpancingo, Guerrero. C.P. 39090, México. ²Departamento de Microbiología, Facultad de Medicina, Universidad Autónoma de Nuevo León. Av. Madero y Dr. Aguirre S/N, Colonia Mitras Centro, Monterrey N. L. C. P. 64460 México. ${ }^{3}$ Unidad Especializada en Gastroenterología Endoscopia. Privada de Jacarandas No. 5, Col. Residencial Bugambilias, Chilpancingo, Guerrero, C.P. 39090 México. ${ }^{4}$ Laboratorio de Enfermedades Crónico Degenerativas, Unidad Académica de Ciencias Químico Biológicas de la Universidad Autónoma de Guerrero. Chilpancingo, Guerrero, México. ${ }^{5}$ Laboratorio de Biomedicina Molecular, Unidad Académica de Ciencias Químico Biológicas de la Universidad Autónoma de Guerrero. Chilpancingo, Guerrero, México.

\section{Authors' contributions}

All authors read and approved the final study. GFT designed and coordinated the study and wrote the draft. DNMC optimized the PCR 
conditions, carried out molecular analysis and descriptive analysis of the data, and contributed in preparation of the study. EGG directed pyrosequencing and participated in study preparation. EFA conducted statistical data analysis, RBL recruited patients and carried out the endoscopies on gastric biopsies, TMM conducted surveys and carried out PCR, CAR did ELISA and participated in conducting surveys, BIA participated in study design and data analysis, ARR participated in study design and coordination.

\section{Competing interests}

The authors declare that they have no competing interests.

Received: 20 April 2010 Accepted: 27 October 2010

Published: 27 October 2010

\section{References}

1. Rad R, Prinz C, Neu B, Neuhofer M, Zeitner Voland P, Becker I, Schepp W, Gerhard M: Synergistic effect of Helicobacter pylori virulence factors and interleukin-1 polymorphisms for the development of severe histological changes in the gastric mucosa. JID 2003, 188:272-280.

2. Sierra R, Une C, Ramírez V, Alpízar-Alpízar W, González Ml, Ramírez JA, De Mascarel A, Cuenca P, Pérez-Pérez G, Mégraud F: Relation of atrophic gastritis with Helicobacter pylori-CagA+ and interleukin-1 gene polymorphisms. World I Gastroenterol 2008, 14:6481-6487.

3. Fox JG, Wang TC: Inflammation, atrophy, and gastric cancer. J Clin Invest 2007, 117:60-69.

4. Peek RM, Blaser MJ: Helicobacter pylori and gastrointestinal tract adenocarcinomas. Nature 2002, 2:28-37.

5. Zhang Z, Zheng Q, Chen X, Xiao S, Liu W, Lu H: The Helicobacter pylori duodenal ulcer promoting gene, dupA in China. BMC Gastroenterology 2008, 8:49.

6. Garza-González E, Bosques-Padilla FJ, El-Omar E, Hold G, TijerinaMenchaca R, Maldonado-Garza HJ, Pérez-Pérez Gl: Role of the polymorphic IL-1B, IL-1RN and TNF-A genes in distal gastric cancer in Mexico. Int $J$ Cancer 2005, 114:237-241.

7. Marciorkowska E, Roszko I, Kowalczuk O, Kaczmarski M, Chyczewski L, Kemona A: The evaluation of vacA gene allele frequency in Helicobacter pylori strains in adults and children in Podlaskies region. Folia Histochem Cytobiol 2007, 45:215-219.

8. Caricio-Martins L, Oliveira-Corvelo TC, Demachki S, Araujo MTF, BaraúnaAssumpção M, Araujo-Jucá Vilar SC, Bonfim-Freitas F, Melo-Barbosa HP, Alves-Fecury A, Kelly-Costa do Amaral R, Batista-dos Santos SE: Clinical and pathological importance of vacA allele heterogeneity and cagA status in peptic ulcer disease in patients from North Brazil. Mem Inst Oswaldo Cruz 2005, 100:875-881.

9. Chang YH, Wang L, Lee MS, Cheng CW, Wu CY, Shiau MY: Genotypic characterization of Helicobacter pylori cagA and vacA from biopsy specimens of patients with gastroduodenal diseases. Mt Sinai J Med 2006, 73:622-626.

10. Garza-González E, Bocanegra-García V, Bosques-Padilla FJ, FloresGutiérrez JP, Moreno F, Perez-Perez Gl: mRNA levels of TLR4 and TLR5 are independent of $H$ pylori. World J Gastroenterol 2008, 14:5306-5310.

11. Moorchung N, Srivastava AN, Gupta NK, Ghoshal UC, Achyut BR, Mittal B: Cytokine gene polymorphisms and the pathology of chronic gastritis. Singapore Med J 2007, 48:447-454.

12. Kim SH, Mok JW, Kim HS, Joo CK: Association of $-31 \mathrm{~T}>\mathrm{C}$ and $-511 \mathrm{C}>\mathrm{T}$ polymorphisms in the interleukin 1 beta IL1B) promoter in Korean keratoconus patients. Mol Vis 2008, 14:2109-2116.

13. Uno M, Hamajima N, Ito LS, Oba S, Marie SKN, Shinjo SK, Onda H, Saito T, Takezaki T, Tajima K, Tominaga S: Helicobacter pylori seropositivity and IL1B C-31T polymorphism among Japanese Brazilians. Int J Mol Med 2002, 10:321-326.

14. Kato S, Onda M, Yamada S, Matsuda N, Tokunaga A, Matsukura N: Association of the interleukin- $1 \beta$ genetic polymorphism and gastric cancer risk in Japanese. J Gastroenterol 2001, 36:696-9.

15. Santtila S, Savinainen K, Hurme M: Presence of the IL-1RA allele 2 (IL1RN*2) is associated with enhanced IL-1 $\beta$ production in vitro. Scand J Immunol 1998, 47:195-198.

16. Hsu Pl, Li CN, Tseng HH, Lai KH, Hsu PN, Lo GH, Lo CC, Yeh JJ, Ger LP, Hsiao M, Yamoaka Y, Hwang IR, Chen A: The Interleukin-I RN polymorphism and Helicobacter pylori infection in the development of duodenal ulcer. Helicobacter 2004, 9:604-613.

17. Al-Moundhri MS, Al-Nabhani M, Al-Bahrani B, Burney IA, Al-Madhani A, Ganguly SS, Al-Yahyaee SA, Grant CS: Interleukin-1 $\beta$ gene (IL-1B) and interleukin 1 receptor antagonist gene (IL-1RN) polymorphisms and gastric cancer risk in an Omani Arab population. Gastric Cancer 2006, 9:284-290.

18. El-Omar EM: The importance of interleukin $1 \beta$ in Helicobacter pylori associated disease. Gut 2001, 48:743-747.

19. Figueiredo C, Machado JC, Pharoah P, Seruca R, Sousa S, Carvalho R, Capelinha AF, Quint W, Caldas C, van Dooorn L, Carneiro F, SobrinhoSimoes M: Helicobater pylori and Interleukin 1 genotyping: An opportunity to identify high-risk individuals for gastric carcinoma. J Natl Cancer Inst 2002, 94:1680-1686.

20. Pérez-Pérez GI, Garza-González E, Portal C, Olivares AZ: Role of cytokine polymorphisms in the risk of distal gastric cancer development. Cancer Epidemiol Biomarkers Prev 2005, 14:1869-73.

21. Secretaría de Salud, Subsecretaría de Prevención y Promoción de la Salud. Centro Nacional de Vigilancia Epidemiológica y Control de Enfermedades. Dirección General de Epidemiología: Información epidemiológica de morbilidad. México 2006.

22. Dixon MF, Genta RM, Yardley JH, Correa P: Classification and grading of gastritis. The updated Sydney system-International workshop on the histopathology of gastritis, Houston 1994. Am J Surg Pathol 1996, 20:1161-1181.

23. Sambrook J, Russel D: Molecular Cloning a Laboratory Manual EU: Col Spring Harbor Laboratory Press; 2001.

24. Atherton JC, Cao P, Peek RMR Jr, Tummuru MKR, Blasser MJ, Cover TL: Mosaicism in vacuolating cytotoxin alleles of Helicobacter pylori. J Biol Chem 1995, 270:17771-17777.

25. Park CY, Kwak M, Gutierrez O, Graham DY, Yamaoka Y: Comparison of genotyping Helicobacter pylori directly from biopsy specimens and genotyping from bacterial cultures. J Clin Microbiol 2003, 41:3336-3338.

26. Miller SA, Dykes DD, Polesky HF: A simple salting out procedure for extracting DNA from human nucleated cells. Nucleic Acids Res 1988, 16:1215.

27. Pérez-Pérez GI, Portal-Celhay C, Bosques-Padilla FJ, Garza-González E: Desarrollo de un protocolo de pirosecuenciación para la tipificación del polimorfismo -31 del gen de la interleucina $1 \beta$ en el estudio del riesgo al desarrollo de cáncer gástrico. Rev Gastroenterol Mex 2007, 72:136-140.

28. Morales-Espinoza R, Castillo-Rojas G, Gonzalez-Valencia G, Ponce-DeLeon S, Cravioto A, Atherton JC, López-Vidal Y: Colonization of Mexican patients by multiple Helicobacter pylori strains with different vacA and cagA genotypes. J Clin Microbiol 1999, 3001-3004.

29. Garza-González E, Bosques-Padilla FJ, Tijerina-Menchaca R, Pérez-Pérez Gl: Characterisation of Helicobacter pylori isolates from the north-eastern region of Mexico. Clin Microbiol Infect 2004, 10:41-45.

30. Paniagua GL, Monroy E, Rodríguez R, Arroniz S, Rodríguez C, Cortés JL, Camacho A, Negrete E, Vaca S: Frequency of vacA, cagA and babA2 virulence markers in Helicobacter pylori strains isolated from Mexican patients with chronic gastritis. Ann Clin Microbiol Antimicrob 2009, 8:14.

31. Ruzzo A, Graziano F, Pizzagalli F, Santini D, Battistelli V, Panunzi S, Canestrari E, Catalano V, Humar B, Ficarelli R, Bearzi I, Cascinu S, Naldi N, Testa E, Magnani M: Interleukin 1B gene (IL-1B) and interleukin 1 receptor antagonist gene (IL-1RN) polymorphisms in Helicobacter pylorinegative gastric cancer of intestinal and diffuse histotype. Ann Oncol 2005, 16:887-92

32. El-Omar EM, Carrington M, Chow WH, McColl KE, Breamk JH, Young HA, Herrera J, Lissowska J, Yuan CC, Rothman N, Lanyon G, Martin M, Fraumeni JF, Rabkin CS: Interleukin-1 polymorphisms associated with increased risk of gastric cancer. Nature 2000, 404:398-402.

33. Chang YW, Jang JY, Kim NH, Won-Lee J, Jung-Lee J, Won-Jung W, Dong SH, Kim HJ, Kim BH, Lee JI, Chang R: Interleukin-1B (IL-1B) polymorphisms and gastric mucosal levels of IL-1 $\beta$ cytokine in Korean patients with gastric cancer. Int J Cancer 2005, 114:465-471.

34. Kamangar F, Cheng C, Abnet CC, Rabkin CS: Interleukin-1B polymorphisms and gastric cancer risk-a meta-analysis. Cancer Epidemiol Biomarkers Prev 2006, 15:1920-8.

35. Prinz C, Schwendy Voland P: H. pylori and gastric cancer: Shifting the global burden. World I Gastroenterology 2006, 12(Suppl 34):5458-5464.

36. Saijo Y, Yoshioka E, Fukui T, Kawaharada M, Sata F, Sato H, Kishi R: H pylori 
seropositivity and cytokine gene polymorphisms. World I Gastroenterol 2007, 13:4445-4451.

37. Matsukura N, Yamada S, Kato S, Tomtitchong P, Tajiri T, Miki M, Matsuhisa T, Yamada N: Genetic differences in interleukin-1 beta polymorphisms among four Asian populations: An analysis of the Asian paradox between $H$. pylori infection and gastric cancer incidence. J Exp Clin Cancer Res 2003, 22:47-55.

38. Yamada S, Matsuhisa T, Makonkawkeyoon L, Chaidatch S, Kato S, Matsukura N: Helicobacter pylori infection in combination with the serum pepsinogen $\mathrm{I} / \mathrm{I}$ ratio and interleukin-1b-511 polymorphisms are independent risk factors for gastric cancer in Thais. J Gastroenterol 2006, 41:1169-1177.

39. Katsuda N, Hamajima N, Tamakoshi A, Wakai K, Matsuo K, Saito T, Tajima K, Tominaga S: Helicobacter pylori seropositivity and the myeloperoxidase G-463A polymorphism in combination with interleukin-1B C-31T in Japanese health checkup examinees. Jpn J Clin Oncol 2003, 33:192-197.

40. García-González MA, Lanas A, Savelkoul PHM, Santolaria S, Benito R, Crusius JBA, Peña AS: Association of interleukin 1 gene family polymorphisms with duodenal ulcer disease. Clin Exp Immunol 2003, 134:525-531.

41. Sicinschi LA, López-Carrillo L, Camargo MC, Correa P, Sierra RA, Henry RR, Jia C, Zabaleta J, Piazuelo MB, Schneider BG: Gastric cancer risk in a Mexican Population: Role of Helicobacter pylori cagA positive infection and polymorphisms in interleukin-1 and -10 genes. Int I Cancer 2006, 118:649-657.

42. Silva-Zolezzi I, Hidalgo Miranda A, Estrada Gil1 J, Fernández López JC, Uribe Figueroa L, Contreras A, Balam Ortiz E, del Bosque Plata L, Lara C, Velázquez Fernández D, Goya R, Hernández Lemus E, Dávila C, Barrientos E, March S, Jiménez-Sánchez G: Análisis de la diversidad genómica en las poblaciones mestizas mexicanas para desarrollar medicina genómica en México. Proc Natl Acad Sci U S A. 2009, 106(21):8611-8616.

43. Furuta T, El-Omar EM, Xiao F, Shirai N, Takashima M, Sugimura H: Interleukin 1beta polymorphisms increase risk of hypochlorhydria and atrophic gastritis and reduce risk of duodenal ulcer recurrence in Japan. Gastroenterology 2002, 123:92-105.

44. Hwang IR, Kodama T, Kikuchi S, Sakai K, Peterson LE, Graham DY, Yamaoka Y: Effect of interleukin 1 polymorphisms on gastric mucosal interleukin $1 \beta$ production in Helicobacter pylori infection. Gastroenterology 2002, 123:1793-803.

45. Chakravortya M, Datta D, Choudhuryb A, Roychoudhurya S: IL1B promoter polymorphism regulates the expression of gastric acid stimulating hormone gastrin. Int J Biochem Cell Biol 2009, 41:1502-1510.

46. Zeng ZR, Hu PJ, Hu S, Pang RP, Chen MH, Ng M, Sung JJY: Association of interleukin 1B gene polymorphisms and gastric cancers in high and low prevalence regions in China. Gut 2003, 52:1684-9.

47. Takagi A, Deguchi R, Kobayashi K, Miwa T: Cytokine expressions and $H$. pylori-associated gastric mucosal lesion. Keio J Med 2002, 51(Suppl 2):51-2.

\section{Pre-publication history}

The pre-publication history for this paper can be accessed here: http://www.biomedcentral.com/1471-230X/10/126/prepub

doi:10.1186/1471-230X-10-126

Cite this article as: Martínez-Carrillo et al: Association of IL1B -511C/-31T haplotype and Helicobacter pylori vacA genotypes with gastric ulcer and chronic gastritis. BMC Gastroenterology 2010 10:126.

\section{Submit your next manuscript to BioMed Central and take full advantage of:}

- Convenient online submission

- Thorough peer review

- No space constraints or color figure charges

- Immediate publication on acceptance

- Inclusion in PubMed, CAS, Scopus and Google Scholar

- Research which is freely available for redistribution

Submit your manuscript at www.biomedcentral.com/submit 